The Last Titan 
This page intentionally left blank 


\section{JEROME LOVING}

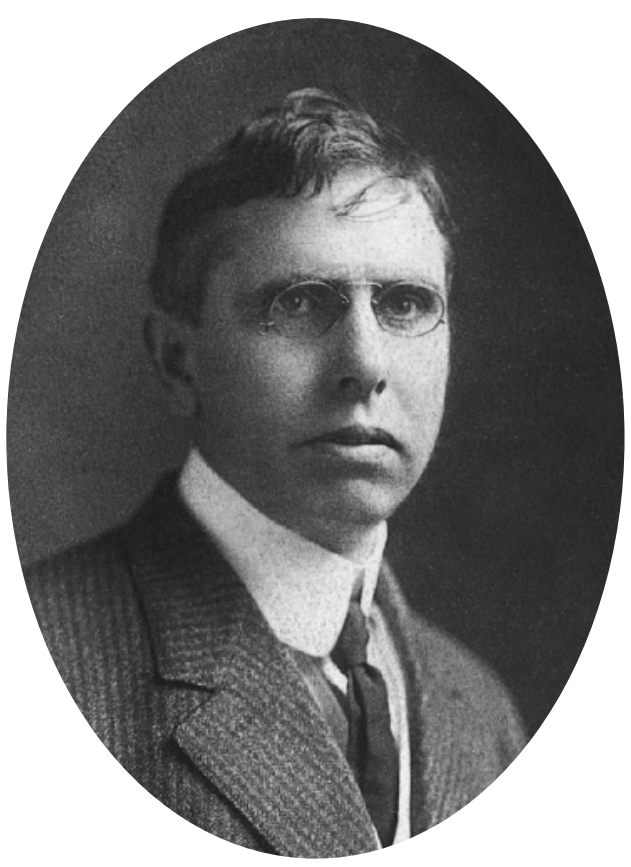

The Last Titan

A Life of Theodore Dreiser

UNIVERSITY OF CALIFORNIA PRESS

BERKELEY LOS ANGELES LONDON 
University of California Press

Berkeley and Los Angeles, California

University of California Press, Ltd.

London, England

(C) 2005 by the Regents of the University of California

Library of Congress Cataloging-in-Publication Data

Loving, Jerome.

The last titan : a life of Theodore Dreiser / Jerome Loving.

p. $\mathrm{cm}$.

Includes bibliographical references and index.

ISBN 0-520-2348I-2 (alk. paper)

I. Dreiser, Theodore, I87I-I945. 2. Novelists,

American - 2oth century-Biography.

3. Journalists — United States - Biography.

I. Title.

PS3507.R55Z6655 2005

$8 \mathrm{I}^{\prime} .52-\mathrm{dc} 22$

2004016270

Manufactured in the United States of America

$\begin{array}{llllllllll}\text { I4 } & \text { I3 } & \text { I2 } & \text { II } & \text { IO } & 09 & 08 & 07 & 06 & 05\end{array}$

$\begin{array}{llllllllll}\text { IO } & 9 & 8 & 7 & 6 & 5 & 4 & 3 & 2 & \text { I }\end{array}$

The paper used in this publication meets the minimum requirements of ANSI/NISO Z39.48-1992 (R 1997) (Permanence of Paper). 
Like Walt Whitman, another shaggy outsider, Dreiser elbowed himself into the company of Leading American Authors without the proper credentials.

DANIEL AARON 
This page intentionally left blank 
TO MARY LOVING

TO THE MEMORY OF DENNIS CREIGHTON 
This page intentionally left blank 